\title{
Stocker cattle performance and vegetation response to intensive-early stocking of Cross Timbers rangeland
}

\author{
F.T. MCCOLLUM, R.L. GILLEN, D.M. ENGLE, AND G.W. HORN
}

\begin{abstract}
A 4-year study was conducted on Cross Timbers range in northcentral Oklahoma. Conventional seasonlong grazing (SLS) of stocker cattle was compared to intensive-early season stocking (IES). Stocking density was increased 2-fold on the IES system but stocking rate was the same relative to SLS. Grazing treatments were applied in a manner that allowed each pasture to be grazed under each management system. Midseason standing crop of grazed residue was lower under IES but there was no difference in end-of-season standing crop. In July, tallgrass residue and forb residue were lower on IES pastures while residue of little bluestem and other grasses was not affected by grazing treatment. End-ofseason standing crop of tallgrass residue was similar because of late-season regrowth under IES and continued defoliation under SLS. Distribution of utilization was not improved by IES. Cattle gains (kg/head) during the early-season were similar for both grazing programs. Total beef production was increased $19 \%$ by IES as a result of increased stocking density. Our results indicate that IES can be utilized to improve cattle production from Cross Timbers ranges.
\end{abstract}

Key Words: oak-hickory forest, tallgrass prairie, intensive stocking, cattle, weight gain, forage utilization, standing crop

Stocking capacity and therefore beef production from ranges in the Cross Timbers resource area are low relative to surrounding

\footnotetext{
McCollum and Gillen are associate professors of animal science and range science, respectively; Engle and Horn are professors of range science and animal science, respectively, Oklahoma State University, Stillwater 74078-0425.

Research was funded by the Oklahoma Agricultural Experiment Station and is published as Journal Manuscript No. 5526.

Manuscript accepted 21, June 1989.
}

resource areas in Kansas and Oklahoma. The conventional approach to increasing beef production on these areas has been mechanical or chemical reduction of the brush canopy. However as these methods become more cost prohibitive, livestock producers will seek other means of increasing production. Intensive grazing practices may partially achieve this goal. A potential means of increasing beef production with stocker cattle is intensive-early stocking.

Hart (1978) proposed that livestock response to stocking density varies in relation to the quantity and quality of forage available to the grazer. During periods of the growing season when the forage resource is homogeneously green and leafy, and growth is relatively rapid, stocking density will have little influence on livestock performance. In addition, weight gains by grazing cattle are at their peak during these periods of the year. The combined effects of greater stocking density and normally peak seasonal gains can significantly improve gain per unit of grazing area over a short period of time.

Studies on shortgrass range in Colorado (Klipple 1964) and Kansas (Olson 1987), and tallgrass range in the Flint Hills of Kansas (Launchbaugh and Owensby 1978) have demonstrated that stocking density can be increased 2 to 3-fold during the early growing season without affecting gains of growing cattle. Intensiveearly stocking also improved the distribution of utilization on tallgrass prairie (Smith and Owensby 1978). The following study was conducted to evaluate the influence of intensive-early season stocking on short-term standing crop dynamics, grazing distribution, and cattle production on Cross Timbers range in Oklahoma. 


\section{Materials and Methods}

\section{Study Site}

The study was conducted on the Pawhuska Research Station located in Osage County approximately $45 \mathrm{~km}$ NNW of Tulsa, Okla. Climate is moist, subhumid with an average winter temperature of $3.3^{\circ} \mathrm{C}$ and an average summer temperature of $33.3^{\circ} \mathrm{C}$. The average annual total precipitation is $88 \mathrm{~cm}$, of which $66 \%$ occurs during the period from April through September, the growing season for range vegetation in this area (Medlyn and Carter 1984). For the period October 1983 through September 1987, precipitation in Pawhuska was $47 \%$ above normal.

The study site is a mosaic of fine and coarse textured soils producing tallgrass prairie and oak-hickory forest vegetation types typical of the Cross Timbers resource area. Prairie soils were loams and silt loams classified as either Typic Argiudolls, Typic Hapludolls, Aguic Paleudolls, or Vertic Haplustalfs. Vegetation of the prairie is dominated by big bluestem (Andropogon gerardii Vitman), switchgrass (Panicum virgatum L.), indiangrass (Sorghastrum nutans (L.) Nash), and little bluestem (Schizachyrium scoparium (Michx.) Nash). Other grasses include sideoats grama (Bouteloua curtipendula (Michx.) Torr.), tall dropseed (Sporobolus asper (Michx.) Kunth), and Scribner's panicum (Dicanthelium oligosanthes (J.A. Schultes) Gould). The dominant forb is western ragweed (Ambrosia psilostachya DC.). These sites occur as broad expanses or as small openings in the oak-hickory forest (Medlyn and Carter 1984).

The forest soils were loams classified as either Udic Ustochrepts, Aquic Paleustalfs, or Ultic Haplustalfs. The soil supports an oakhickory forest with a mixture of hardwoods (Medlyn and Carter 1984). Vegetation on these sites is characteristically a closed forest or resprout thicket. Blackjack oak (Quercus marilandica Muenchh.) and black hickory (Carya texana Buckley) are the dominant tree species representing more than $50 \%$ of the tree basal area on the station. Other tree species include post oak ( $Q$. stellata Wang.) and American elm (Ulmus americana $\mathrm{L}$.). Very little forage production occurs on these sites except on small open prairies interspersed within this vegetation type.

\section{Grazing Treatments}

The study was initiated in 1984 and continued over a 4-year period. Four pastures were selected for use in the study. All pastures contained both prairie and savannah range sites although savannah sites were predominant. Initial seasonlong (April-September) stocking rates were established using a combination of Soil Conservation Service range site guides and stocking history for the pastures. The pastures were not burned during the 4-year study.

Two grazing treatments, seasonlong stocking (SLS) and intensiveearly stocking (IES), were applied to each pasture in alternate years (Table 1). Season-long stocking is defined as continuous grazing from late-April until late-September at a recommended moderate stocking rate. Intensive-early stocking is defined as continuous

Table 1. Treatment assignments and graxing periods for experimental pastures, $1984-1987$.

\begin{tabular}{|c|c|c|c|c|c|c|c|}
\hline \multirow[b]{2}{*}{ Year } & \multicolumn{4}{|c|}{ Pasture } & \multicolumn{3}{|c|}{ Grazing Periods } \\
\hline & 1 & 2 & 3 & 4 & Start & Mid- & End \\
\hline $\begin{array}{l}1984 \\
1985 \\
1986 \\
1987\end{array}$ & $\begin{array}{l}\text { IES } \\
\text { SLS } \\
\text { IES } \\
\text { SLS }\end{array}$ & $\begin{array}{l}\text { SLS } \\
\text { IES } \\
\text { SLS } \\
\text { IES }\end{array}$ & $\begin{array}{l}\text { IES } \\
\text { SLS } \\
\text { IES } \\
\text { SLS }\end{array}$ & $\begin{array}{l}\text { SLS } \\
\text { IES } \\
\text { SLS } \\
\text { IES }^{\mathrm{a}}\end{array}$ & $\begin{array}{l}27 \text { April } \\
24 \text { April } \\
12 \text { April } \\
14 \text { April }\end{array}$ & $\begin{array}{l}19 \text { July } \\
12 \text { July } \\
17 \text { July } \\
15 \text { July }\end{array}$ & $\begin{array}{l}20 \text { Sept } \\
27 \text { Sept } \\
29 \text { Sept } \\
30 \text { Sept }\end{array}$ \\
\hline
\end{tabular}

ata not inchuded in analyses. grazing from late-April until mid-July at a stock density (head/ha) twice that of SLS but at stocking rate (head*days/ha) similar to SLS.

Mid-July was selected as a termination date for IES based upon previous work in Kansas (Launchbaugh and Owensby 1978). Late September was selected as a termination date for SLS based on cattle management practices in the region. Actual calendar dates of activities are shown in Table 1.

\section{Experimental Livestock}

Initial weight of the cattle used in all 4 years averaged $236 \mathrm{~kg}$. In 1984 , the steers had been wintered on the Station prior to summer grazing. In subsequent years, cattle were delivered to the station in March. In 1985 and 1987 , cattle were shipped directly to the station following purchase and preconditioned for 28 days prior to grazing; in 1986, cattle were preconditioned prior to delivery. With the exception of 1987, cattle were predominantly British/European crossbred, yearling (12-14 mo. of age) beef steers. Cattle grazed in 1987 were crossbred yearling steers $(27 \%)$ and bulls $(73 \%)$ with 25-50\% Zebu breeding. Bulls were castrated immediately prior to the initiation of grazing. All cattle were implanted (Ralgro ${ }^{\text {tm }}$ or Synovex $-S^{t m}$ ) at the start of the grazing season. Additionally, SLS steers were fed $0.5 \mathrm{~kg} /$ head/day of a $38 \%$ protein supplement from mid-July to the end of September. Cattle had ad libitum access to a commercial mineral supplement ( $12 \%$ calcium; $7 \%$ phosphorus; containing either chlortetracycline or monensin) throughout each summer.

\section{Field Dats}

All cattle were weighed at the start of the trials and when the IES treatment was terminated. The SLS cattle were weighed again when SLS grazing was terminated. All weights were recorded between 0700 and $1000 \mathrm{~h}$. The cattle were gathered between 1600 and $1800 \mathrm{~h}$ the evening before weighing and held overnight in drylot without feed or water.

Total steer days of grazing and total beef production for the grazing treatments were compared in the following manner. Total steer days of grazing for SLS was equal to the length of the grazing season. Total steer days of grazing for intensive-early stocking was computed as the product of the length of the early-season grazing period and the stocking density factor 2 . Total production was computed as the product of gain*steer ${ }^{-1 *}$ day $^{-1}$ and total steer days of grazing.

Standing crop and species composition of grazed herbage residues and utilization of key species were measured twice annually in each pasture. Observations were recorded in mid-July after the IES treatment was terminated and in October after the SLS pastures had been vacated. Thirty random sample points were located in each pasture at the start of the study. Utilization of big bluestem and little bluestem was visually estimated (Anderson and Currier 1973) in the area surrounding each point. Estimates were scored from 1 to $5(1=0-15 \%$ use; $2=15-40 \%$ use; $3=40-60 \%$ use; 4 $=60-80 \%$ use; $5=80-100 \%$ use). Midpoint percentages for each rank were used to convert field observations into percentage estimates reported in the text. The coefficient of variation of individual measurements within pastures was calculated as an indication of uniformity of grazing within a pasture.

Standing crop was measured on 10 of the 30 points by clipping herbage to ground level inside $4,50 \times 50 \mathrm{~cm}\left(0.25 \mathrm{~m}^{2}\right)$ quadrats per point. Clipped samples were dried at $100^{\circ} \mathrm{C}$ for $96 \mathrm{~h}$ to determine dry sample weight. Herbage composition was estimated prior to clipping using the dry-weight-rank method described by Gillen and Smith (1986). Components were broadly classified into vegetation classes of tallgrasses, little bluestem, other grasses and forbs. Standing crop and composition data were combined and reported 
as total standing crop and standing crop for specific vegetation classes.

\section{Data Analyses}

All analyses were conducted using the General Linear Models procedure of the Statistical Analysis System. Least squares procedures were used to estimate means.

Data from one pasture in 1985 and 1987 were excluded from the analysis (Table 1). In 1985, oil exploration activity in pasture 2 reduced surface acreage of forage and as a result cattle grazing had to be terminated at midseason rather than in late September. In 1987, grazing on an IES unit had to be terminated in early June due to a lack of forage. This pasture had been successfully grazed on both treatments in previous years. The problems in 1987 are thought to be the combined result of increased canopy density on savannah sites in the pasture and the lack of rainfall during critical spring months. In 1984, when stocking rates were determined for each pasture, pasture 4 supported a relatively young, open stand of trees on the savannah sites. Hence the stocking capacity for the savannahs in pasture 4 was rated higher than on the other pastures that supported older stands and dense canopies. Above-normal precipitation during the first 3 years of the study increased woody standing crop on other research sites with similar vegetation types (J.F. Stritzke, unpublished data). Therefore we assume that canopy density increased in pasture 4. Additionally, precipitation in March, April, and the first 3 weeks of May, 1987, was only $48 \%$ of normal. The combined influences of increased canopy cover and low rainfall probably acted to increase grazing pressure on this pasture to the point that cattle demands were greater than forage production. This was not a problem on other pastures because the initial stocking capacity was reduced on the savannah sites with dense, mature tree canopies.

Livestock performance data were analyzed as a randomized design with pastures as experimental units. Main effects in the model included year and grazing treatment (GRTRT) and were tested with residual error. Two-way interactions (Year $\times$ GRTRT) were not detected $(P>.10)$ and therefore were pooled with residual error.

Analysis of vegetation data was limited to those points which occurred in open prairie areas. Generally, forage production and utilization in closed savannahs was negligible and therefore biased overall measurement means. Standing crop and species composition data were analyzed using a repeated measures model that included Year, GRTRT, sampling date (midseason vs. end-ofseason), and two- and three-way interactions. Year, GRTRT and Year $\times$ GRTRT were tested with the residual error. Utilization data for the IES-midseason, SLS-midseason, and SLS-end-ofseason were compared with a model containing Year, PAST, GRTRT and Year $\times$ GRTRT. All terms were tested with the residual error term.

\section{Results and Discussion}

\section{Standing Crop and Composition of Residue}

Total residual standing crop, averaged across sampling dates and grazing treatments, generally increased as the 4-year experiment progressed. The primary change occurred in 1985 when forbs and grasses other than little bluestem and the tallgrasses increased (Fig. 1). The greater residual standing crop in successive years is best accounted for by rainfall during the study. Vegetation year precipitation (October to September) was $20 \%, 89 \%, 45 \%$, and $35 \%$ above the longterm average from 1984 through 1987, respectively.

The lack of increase in little bluestem and tallgrasses (primarily big bluestem), relative to other grasses, possibly reflects differences in selectivity by grazing steers. Big bluestem and little bluestem are among the more preferred plant species in tallgrass plant communities (Dwyer 1961, Gillen et al. 1990, Jensen et al. 1990). Increased

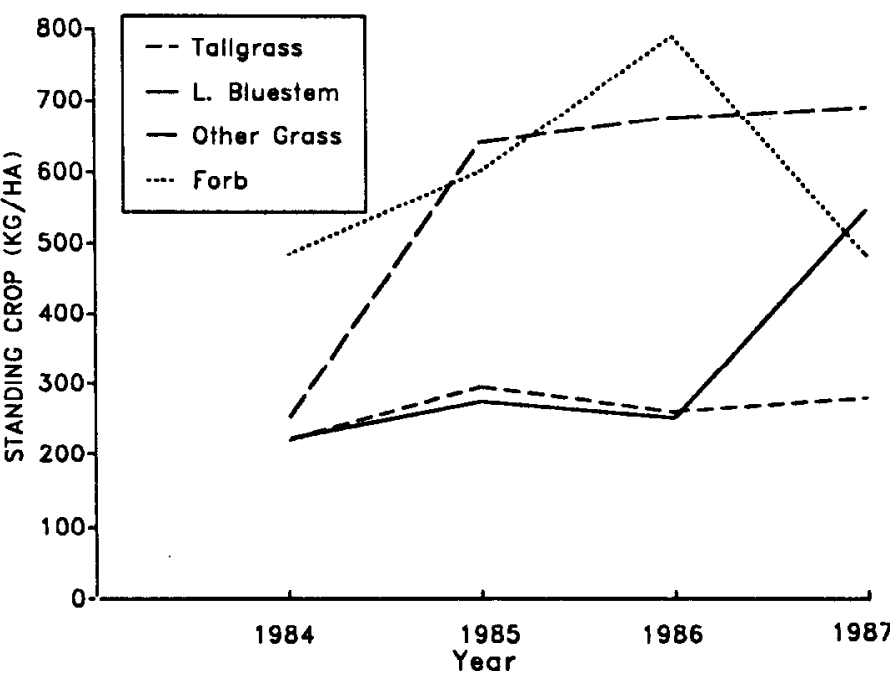

Fig. 1. Influence of year on components of residual standing herbage. Data are averaged across sampling dates and grazing treatments within years.

ities (Dwyer 1961, Gillen et al. 1988, Jensen et al. 1988). Increased production associated with greater precipitation would provide greater amounts of preferred species and thereby reduce grazing pressure on less preferred species.

Grazing treatment $X$ sampling date interactions were noted for total standing crop $(P<0.05)$, tallgrasses $(P<0.01)$, and forbs $(P<0.08)$. At midseason, residual standing crop was $814 \mathrm{~kg} / \mathrm{ha}$ lower on IES pastures than on SLS pastures ( $P<0.001$; Fig. 2 ).

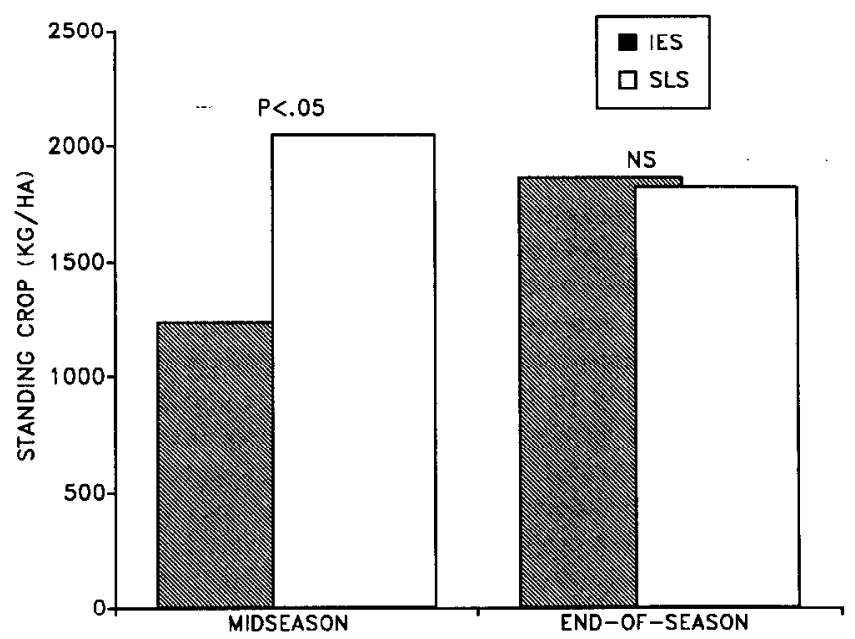

Fig. 2. Total standing crop (kg/ha) following the intensive-early stocking (IES) period (July, midseason) and seasonlong stocking (SLS) period (October, end-of-season).

However, IES pastures had regrown by the end of the grazing season and there were no differences between the treatments. Our results are similar to those reported by Smith and Owensby (1978) on Flint Hills range in northeastern Kansas.

Lower midseason residue levels on IES reflect the greater earlyseason pressure on these pastures. Midseason standing crop residues were only $35 \%$ lower on IES pastures compared to SLS pastures despite a $115 \%$ increase in total grazing days. Smith and Owensby (1978) suggested that early-season growth of perennial grasses was increased under IES because twice as many cattle were grazed without twice the loss of forage. Our midseason measurements reveal that the tallgrass and forb components of total stand- 


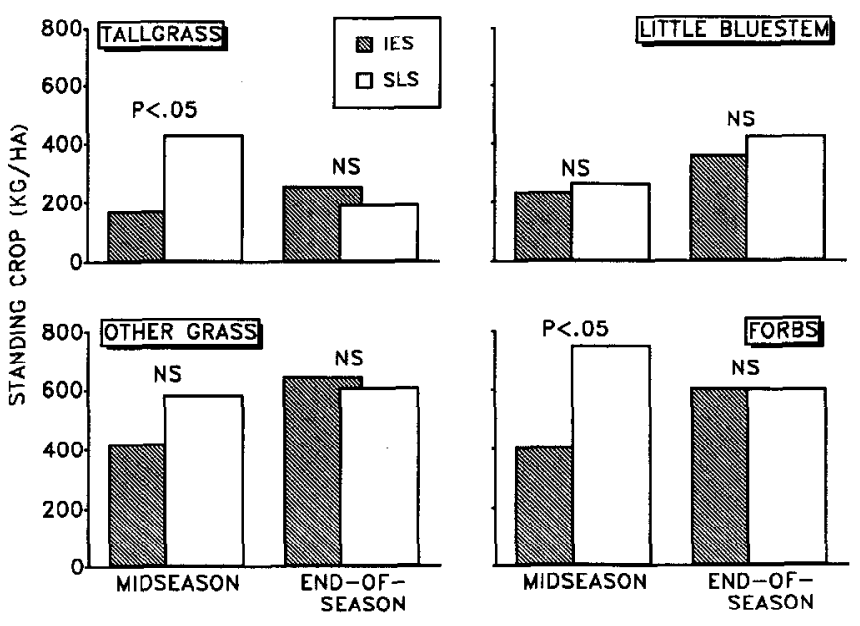

Fig. 3. Standing crop ( $\mathrm{kg} / \mathrm{ha}$ ) of vegetation components following the intensive-early stocking (IES) period (July) and seasonlong stocking (SLS) period (October).

ing crop accounted for the majority of differences between grazing treatments (Fig. 3). Tallgrass residue and forb residue on IES pastures were $60 \%(P<0.05)$ and $46 \%(P<0.10)$ lower in July while residue of little bluestem and other grasses were not affected by grazing treatment. Tallgrass species are the more preferred plant species on these rangelands and would be expected to receive more pressure from livestock compared to other grass components. The apparent greater utilization of forbs is surprising because the predominant species was western ragweed, a relatively unpalatable forb (Dwyer 1961). Kansas researchers also observed an apparent greater use of the forb component on IES pastures (Smith and Owensby 1978).

Grazing practice did not influence components in the end-ofseason standing crop (Fig. 3). Late-season growth in IES pastures and late-season use in SLS pastures resulted in similar residue of tallgrass in October. Late season grazing in the SLS pastures reduced $(P<0.05)$ the tallgrass component to approximately $45 \%$ of the midseason tallgrass standing crop. In contrast, little bluestem standing crop and other grasses remained unchanged $(P>0.10)$ from July through October. Differential late-season use of the various grasses is consistent with the factors responsible for the pattern of range deterioration observed in tallgrass prairie (Launchbaugh and Owensby 1978). Under season-long grazing strategies, big bluestem will be used quite heavily during the summer-fall period. Over a period of time, late-season use reduces vigor of big bluestem and other species such as little bluestem and other midgrasses will increase, apparently due to relatively light use in the late summer. Research in the Kansas Flint Hills has shown that basal cover and percent big bluestem in total standing crop has increased in pastures subjected to IES over a period of years (Smith and Owensby 1978). Early-season use combined with summer-fall non-use improves vigor of big bluestem. Although our pastures were not subjected to the same management regimen over an extended period of years, the short-term observations on early vs. late-season use of big bluestem agree with observations on Kansas rangelands.

\section{Utilization and Grazing Distribution}

Utilization of key species, estimated at the end of the grazing season, averaged $36 \%$ on SLS pastures (Table 2). This degree of use was similar to the utilization on IES pastures in mid-July and $77 \%$ greater than midseason use on SLS pastures. The coefficients of variation (CV) of utilization estimates for each grazing treatment were similar for sampling dates (Table 2). Similarity of the CVs
Table 2. Least squares means and coefficients of variation for utilization percentages for intensive-early stocking and seasonlong stocking.

\begin{tabular}{lcccc}
\hline & \multicolumn{4}{c}{ Sampling date } \\
\cline { 2 - 5 } Grazing treatment & \multicolumn{2}{c}{ Midseason } & \multicolumn{2}{c}{ End-of-season } \\
\hline & $(\%)$ & $(\mathrm{CV})$ & $(\%)$ & $(\mathrm{CV})$ \\
Seasonlong stocking & $20.3^{\mathrm{a}}$ & $74.7^{\mathrm{e}}$ & $36.0^{\mathrm{b}}$ & $51.3^{\mathrm{c}}$ \\
Intensive-early stocking & $38.4^{\mathrm{b}}$ & $53.5^{\mathrm{c}}$ & - & - \\
\hline
\end{tabular}

a,b Means with different superscripts are different $(P<.05)$.

${ }^{\circ}$ Coefficient of variation. Coefficients do not vary among grazing treatment-sampling date combinations.

suggests that grazing distribution was not influenced by grazing treatment. However, our estimates were based primarily upon use of big and little bluestem and therefore represent distribution of use on these species rather than the entire herbaceous component. Smith and Owensby (1978) reported that grazing distribution was improved with IES.

\section{Livestock Production}

Cattle gains during the 4 study years were representative of the range in performance frequently observed on this type of rangeland (Table 3). No year $\times$ GRTRT interactions were detected

Table 3. Annual cattle weights, early- and late-season weight gains, and ratio of early-season gain to total gain of cattle grazed seasonlong.

\begin{tabular}{lcccc}
\hline \hline & & \multicolumn{2}{c}{ Weight gain } & Proportion of \\
\cline { 3 - 5 } Year & $\begin{array}{c}\text { Initial } \\
\text { weight }\end{array}$ & $\begin{array}{c}\text { Early- } \\
\text { season }^{\mathrm{d}}\end{array}$ & $\begin{array}{c}\text { Total } \\
\text { gain }^{\mathrm{e}}\end{array}$ & $\begin{array}{c}\text { gain in } \\
\text { early season }\end{array}$ \\
\hline & & $(\mathbf{k g} / \mathbf{h d})$ & $(\%)$ & \\
1984 & 215 & $94^{\mathrm{a}}$ & $134^{\mathrm{a}}$ & 71 \\
1985 & 247 & $57^{\mathrm{b}}$ & $95^{\mathrm{b}}$ & 67 \\
1986 & 246 & $70^{\mathrm{c}}$ & $99^{\mathrm{b}}$ & 70 \\
1987 & 247 & $59^{\mathrm{b}}$ & $119^{\mathrm{c}}$ & 51 \\
SEM $^{\mathrm{f}}$ & 1.8 & 2.5 & 6.1 & \\
\hline
\end{tabular}

a,b,c Column means with different superscripts are different $(P<.01)$.

${ }^{d}$ Least squares mean for year; year $\times$ grazing treatment interaction was not significant.

${ }^{\text {e}}$ Least squares means for seasonlong stocking treatment $X$ year.

'Standard error of the mean, $n=4$.

therefore annual differences resulted from interacting effects of cattle and environment. Early-season gains and total gains were greatest in 1984 and reflect compensatory weight gain following a winter period in which little weight gain occurred. On the otherhand, early-season gains were least in 1985 and 1987. In 1985, cattle were younger and in better flesh conditions than other years. In $1987,73 \%$ of the cattle were "cutter bulls" that were castrated just prior to the initiation of the grazing season. Early-season gains of the cutter bulls were $18 \%$ less than steers (B. Johnson, personal comm.). However, gains for the entire summer were similar. Grazing season precipitation may have modified livestock performance. Deviations from normal grazing season precipitation were -24.8 , $+62.0,+67.6$, and $+1.0 \%$ in $1984,1985,1986$, and 1987 , respectively. Performance appeared to be inversely related to these deviations in precipitation ( (total gain $=122.13-0.3924(\%$ deviation from average $\left.p p t) ; r^{2}=0.97\right)$ ).

On average, $65 \%$ of the total summer gain was added in the early season. This gain profile is consistent with observations in northcentral Kansas (Owensby 1986) and provides a rather dependable estimator for projecting economies and planning grazing cattle operations in this region of Oklahoma and Kansas. Extrapolating from work by Bernardo and McCollum (1987), cattle would usu- 
ally need to add a minimum of $60 \%$ of their total weight gain in the early-season for IES to be economically advantageous. This level of gain occurred in $\mathbf{3}$ of $\mathbf{4}$ years in our study and most likely would have occurred in all 4 years had a different group of cattle been used in 1987.

Intensive-early stocking treatments received more total days of grazing than SLS pastures (Table 4). However, animal unit-based stocking rates were only $1.5 \%$ greater under IES. Previous Kansas

Table 4. Least squares means for steer days of grazing, total gain and total production for intensive-early stocking and season-long stocking.

\begin{tabular}{lccccc}
\hline \hline $\begin{array}{l}\text { Initial } \\
\text { Grazing } \\
\text { treatment }\end{array}$ & $\begin{array}{c}\text { Total } \\
\text { steer } \\
\text { weight, } \\
\text { days of }\end{array}$ & $\begin{array}{c}\text { Early } \\
\text { season } \\
\text { grazing }\end{array}$ & $\begin{array}{c}\text { Total } \\
\text { season } \\
(\mathbf{k g} / \mathbf{h d})\end{array}$ & $\begin{array}{c}\text { Total } \\
\text { gain } \\
(\mathbf{k g} / \mathbf{h d})\end{array}$ & $\begin{array}{c}\text { pro- } \\
\text { duction } \\
(\mathbf{k g})\end{array}$ \\
\hline $\begin{array}{l}\text { Season-long } \\
\text { stocking }\end{array}$ & 240 & 159 & $73^{\mathrm{a}}$ & $113^{\mathrm{a}}$ & $113^{\mathrm{a}}$ \\
$\begin{array}{l}\text { Intensive-early } \\
\text { stocking }\end{array}$ & 239 & 172 & $67^{\mathrm{a}}$ & $67^{\mathrm{b}}$ & $134^{\mathrm{b}}$ \\
$\begin{array}{l}\text { SEM } \\
\text { SEM }\end{array}$ & & & 2.5 & 3.5 & 4.4 \\
\hline
\end{tabular}

a,b Column with different superscripts are different, $(P<.01)$.

'Standard error of the mean, $n=7$

research had limited the IES grazing period to almost exactly one-half of the conventional SLS period. We had longer IES periods as a result of initiating the grazing season prior to 1 May.

Gain during the early-season was similar $(P>0.10)$ for IES and SLS. Hart (1978) hypothesized that animal performance during periods of rapid forage growth would not be greatly affected by increased stocking intensity. Our results and those from studies in eastern Colorado (Klipple 1964), western Kansas (Olson 1987) and eastern Kansas (Smith and Owensby 1978) support Hart's hypothesis.

Total seasonal production improved $19 \%(P<0.05)$ with IES as a result of the increased stocking density. In previous Kansas studies on tallgrass prairie, improvements in total production have ranged from 0 to $48 \%$ over several years (Owensby 1986). The Kansas comparisons were made on burned pastures and therefore may not be valid comparisons of our results.

\section{Conclusions}

The intention of this study was to characterize short-term influences of IES on standing crop components, distribution of utilization, and livestock production on rangeland composed of a mixture of oak-hickory forest and tallgrass prairie range types. Our data on grazed herbage residue suggest that IES would have a beneficial impact on the plant communities on these rangelands. Midseason standing crop residues suggested that either efficiency of forage use was improved or total forage production was increased by allocating grazing to the first half of the conventional grazing season. End-of-season standing crop of the more preferred tallgrass species increased significantly under IES but declined after midseason under SLS. Because desirable warm-season tallgrasses are favored more by late-season non-use in IES compared to SLS, IES is expected to be a beneficial tool for range improvement regardless of its influences on total livestock production.

Total beef production increased under IES but the increases noted in our study were lower than increases noted on tallgrass prairie in Kansas. The relative differences may be associated with the cattle used in 1987 which resulted in more of the total seasonal gain allocated to the late season. These problems emphasize the need to match cattle with potential for rapid gains to the IES program.

\section{Literature Cited}

Anderson, E.W., and W.F. Currier. 1973. Evaluating zones of utilization. J. Range Manage. 26:87-91.

Bernardo, D.B., and F.T. McCollum. 1987. An economic analysis of intensive-early stocking. Oklahoma Agr. Exp. Sta. Res. Rep. P-887.

Dwyer, D.D. 1961. Activities and grazing preferences of cows with calves in northern Osage County, Oklahoma. Oklahoma Agr. Exp. Sta. Bull. B-588.

Gillen, R.L., and E.L. Smith. 1990 . Evaluation of the dry-weight-rank method for determining the species composition of tallgrass prairie. J. Range Manage. 39:283-285.

Gillen, R.L., F.T. McCollum, and J.E. Brummer. 1988. Tiller defoliation patterns under short duration grazing in the tallgrass prairie. J. Range Manage. (Submitted).

Hart, R.H. 1978. Stocking rate theory and its application to grazing management. p. 547-550. In: D.N. Hyder (ed.) Proc. 1st. Int. Rangelands Cong. Society for Range Management, Denver, Colo.

Jensen, H.P., R.L. Gillen, and F.T. McCollum. 1990. Effects of herbage allowance on defoliation patterns of tallgrass prairie. J. Range Manage. (Accepted).

Klipple, G.E. 1964. Early- and late-season grazing versus season-long grazing of short-grass vegetation on the Central Great Plains. U.S. Forest Serv. Res. Pap. RM-11. 16 pp.

Launchbaugh, J.L., and C.E. Owensby. 1978. Kansas Rangelands: Their management based upon a half century of research. Kansas Agr. Exp. Sta. Bull. 622. pp. 16-20.

Medlyn, G., and B. Carter. 1984. Modern detailed soil survey-Pawhuska Research Station, Pawhuska. Oklahoma Agr. Exp. Sta. Res. Rep. P-846.

Olson, K.C. 1987. Intensive-early stocking of western Kansas shortgrass rangeland. Kansas Agr. Exp. Sta. Prog. Rep. 525, pp. 92-98.

Owensby, C.E. 1986. Intensive-early stocking on Kansas Flint Hills range. Proc. 12th annual Oklahoma-Kansas Cattle Conference. Oklahoma Coop. Ext. Serv.

Smith, E.F., and C.E. Owensby. 1978. Intensive-early stocking and seasonlong stocking of Kansas Flint Hills range. J. Range Manage. 31:14-17. 